\title{
NOVEL MONOCLONAL ANTIBODY TO FIBRIN(OGEN) aC-REGION FOR DETECTION OF THE EARLIEST FORMS OF SOLUBLE FIBRIN
}

\author{
N. E. LUGOVSKA ${ }^{1}$, I. M. KOLESNIKOVA ${ }^{1}$, Ye. M. STOHNII', V. O. CHERNYSHENKO ${ }^{\circledR}$, \\ A. V. REBRIEV ${ }^{1}$, O. P. KOSTIUCHENKO ${ }^{1}$, G.K. GOGOLINSKA ${ }^{1}$, N. A. DZIUBLIUK ${ }^{2}$, \\ L. D. VARBANETS ${ }^{2}$, T. M. PLATONOVA ${ }^{1}$, S. V. KOMISARENKO \\ ${ }^{1}$ Palladin Institute of Biochemistry, National Academy of Sciences of Ukraine, Kyiv; \\ ${ }^{2}$ Zabolotny Institute of Microbiology and Virology,National Academy of Sciences of Ukraine, Kyiv; \\ e-mail: bio.cherv@gmail.com
}

Received: 08 May 2020; Accepted: 30 June 2020

\begin{abstract}
Obtaining new monoclonal antibodies (mAbs) towards fibrin(ogen) and its fragments is an important task for studying mechanisms of blood clot formation, searching for novel antithrombotic agents and developing immunodiagnostics. The aim of the present work was to create and characterize a new mAb towards the fibrin(ogen) $\alpha C$-region. We surmise that having a specific $m A b$ towards this flexible part of the molecule will allow us to study the role of the $\alpha C$-region in fibrin polymerization and also to develop an approach for detecting the earliest forms of soluble fibrin by sandwich ELISA. Using hybridoma technology we obtained $m A b$ 1-5A to the $\alpha C$-region of fibrinogen.. It was characterized using several variations of ELISA and Western blot. Application of specific proteases together with MALDI-TOF analysis allowed us to localize its epitope that is

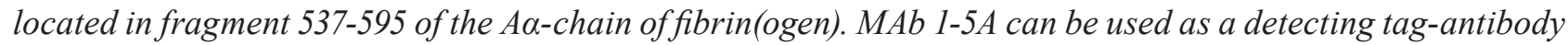
in sandwich ELISA for the quantification of the earliest forms of soluble fibrin which are uncleaved by plasmin and preserved C-terminal portions of $\alpha C$-regions. These earliest forms of soluble fibrin are direct evidence of blood coagulation system activation, thrombin generation and the danger of intravascular thrombus formation. Their determination will provide additional, more accurate information about the state of the blood coagulation system and the risk of blood clotting, which is very important for the timely and correct selection of adequate antithrombotic therapy. MAb 1-5A effectively binds the $\alpha C$-containing molecules of fibrinogen and fibrin in blood plasma. It also can be used for studying protein-protein and protein-cellular interactions of the $\alpha C$-regions of fibrin(ogen).
\end{abstract}

Keywords: monoclonal antibody, fibrinogen, fibrin, $\alpha$ C-region of the fibrin(ogen) molecule, hemostasis, immunodiagnostics.

\section{Introduction}

Monoclonal antibodies (mAbs) to protein molecules and their fragments are used for molecular probing of structure and functions of proteins, mechanisms of their conversions, and immunochemical detection, as well as for targeted delivery of biologically active compounds and immunohistochemistry [1-8].

Fibrinogen is a crucial protein of the blood coagulation system that is converted to fibrin under the action of thrombin, followed by spontaneous polymerization of fibrin to form the core of a thrombus $[7,9]$. These are the reasons why the study of the structure and functions of fibrinogen and fibrin as well as their fragments is of interest for investigation of blood clot formation, development of new antithrombotic drugs and immunodiagnostics. The $\mathrm{mAbs}$ that were previously produced against fibrinogen, fibrin or its fragments have allowed identification of new fibrin polymerization sites [7, 10-15] and creation of numerous immunodiagnostic techniques [7, 16-24]. Development of antithrombotic agents

(C) 2020 Lugovska N. E. et al. This is an open-access article distributed under the terms of the Creative Commons Attribution License, which permits unrestricted use, distribution, and reproduction in any medium, provided the original author and source are credited. 
based on immunoglobulins has also been widely discussed [25].

One of most promising targets for production of mAbs towards the fibrinogen molecule are the $\alpha \mathrm{C}$ regions of fibrinogen formed by the Aa221-610 fragment. The functional role of these regions is still not fully understood [26]. Structurally organized residues A $\alpha 392-610$ of the $\alpha \mathrm{C}$-regions are the most interesting objects for study [27] and for development of specific mAbs targeted to them [28]. Such anti$\alpha \mathrm{C}$-region antibodies can also be used as the tags for the detection of fibrinogen or soluble fibrin, in particular the earliest forms that preserve $\alpha \mathrm{C}$-regions uncleaved by plasmin that are extremely important for the determination of dangerous intravascular thrombus formation [29-31].

Taking into account the value of broadening the available panel of $m A b s$ towards different fragments of fibrinogen $\alpha \mathrm{C}$-regions, in this study we aimed to create and characterize such an antibody for its further use in fibrin polymerization studies and for developing immunodiagnostic approaches.

\section{Materials and Methods}

Reagents. The following reagents were used in the experiments: serum albumin, Tris ([hydroxymethyl] aminomethane, (Sigma-Aldrich, Missouri, USA), acrylamide (Fluka, Buchs, Switzerland), $\mathrm{N}, \mathrm{N}$-methylenebisacrylamide (Acros organics, Geel, Belgium), Coomassie Brilliant Blue R-250 (Sigma-Aldrich), molecular weight calibration kits LMW (14,400 - 94,000 (Pharmacia, Stockholm, Sweden), $\mathrm{KH}_{2} \mathrm{PO}_{4}, \mathrm{NaCl}, \mathrm{NaOH}, \mathrm{HCl}, \mathrm{NaN}_{3}$, urea, $\mathrm{H}_{2} \mathrm{SO}_{4}$, bovine serum albumin (BSA), Complete and Incomplete Freund's Adjuvants (Sigma-Aldrich), skim milk powder (Fluka), Coomassie G250, ammonium persulfate, acrylamide, N,N-methylenebisacrylamide, conjugate of IgG horseradish peroxidase (HRP) (Thermo Scientific, Waltham, Massachusetts, USA), tricine, molecular weight markers for protein gel electrophoresis (Thermo Scientific), $\beta$-mercaptoethanol, Tween-20 (Helicon, Moscow, Russia), $\mathrm{H}_{2} \mathrm{O}_{2}$ (Kyivmedpreparat, Kyiv, Ukraine), glycerol, $\mathrm{KCl}, \mathrm{Na}_{2} \mathrm{HPO}_{4}$, (Miranda-C, Kyiv, Ukraine), and sodium dodecyl sulfate (SDS) (Sigma-Aldrich). Thrombin was purchased from Sigma, USA.

Blood plasma samples. Patients (36 women, 52 men) with stage $\mathrm{V}$ chronic kidney disease who were treated by program hemodialysis were recruited from the Research Institute of Rehabilitation of Vin- nytsia National Pirogov Memorial Medical University (Vinnytsia, Ukraine). Blood plasma was collected into sterile plastic $10 \mathrm{ml}$ tubes where it was mixed immediately with $38 \mathrm{~g} / \mathrm{l}$ sodium citrate (9 parts blood to 1 part sodium citrate). Blood was spun down at $160 \mathrm{~g}$ for $30 \mathrm{~min}$ at $25^{\circ} \mathrm{C}$. Platelet poor plasma was obtained by centrifugation at $300 \mathrm{~g}$ for $15 \mathrm{~min}$. Studies were conducted according to the Ethical Committee Approval N 14 form 01.03.2018 (Vinnytsia National Pirogov Memorial Medical University).

Fibrinogen-Sepharose was synthesized using commercially available BrCN-activated Sepharose CL-4B (Sigma-Aldrich) according to the method of Heene et al. [32]. For this synthesis the matrix was washed for $15 \mathrm{~min}$ on glass filter using $0.001 \mathrm{M} \mathrm{HCl}$. The buffer was then changed to $0.1 \mathrm{M} \mathrm{K}_{2} \mathrm{HPO}_{4}$, pH 7.8 and the matrix was mixed with $20 \mathrm{ml}$ of $0.5-0.75 \%$ solution of fibrinogen in the same buffer. The matrix was incubated for 3 hours at room temperature with agitation. Then the matrix was placed on the glass filter and washed with $0.1 \mathrm{M}$ Tris- $\mathrm{H}_{3} \mathrm{PO}_{4}, \mathrm{pH} 8.6$ with $1 \mathrm{M} \mathrm{NaCl}$ and $0.025 \mathrm{M}$ of $\varepsilon$-aminocapronic acid. Then the buffer was serially changed to $0.1 \mathrm{M} \mathrm{K}_{2} \mathrm{HPO}_{4}, \mathrm{pH} 7.8 ; 0.1 \mathrm{M}$ Tris- $\mathrm{H}_{3} \mathrm{PO}_{4}$, $\mathrm{pH} 4.5$ with $1 \mathrm{M} \mathrm{NaCl}$ and $0.025 \mathrm{M} \varepsilon$-aminocapronic acid; $0.1 \mathrm{M} \mathrm{K}_{2} \mathrm{HPO}_{4}, \mathrm{pH} 7.8$ and finally to $0.1 \mathrm{M}$ $\mathrm{K}_{2} \mathrm{HPO}_{4}, \mathrm{pH} 7.8$, with $0.2 \mathrm{M}$ glycine and left at agitation for $40 \mathrm{~min}$. The ready for use preparation of Fibrinogen-Sepharose was washed on the glass filter with $0.05 \mathrm{M}$ Tris- $\mathrm{H}_{3} \mathrm{PO}_{4}, \mathrm{pH} 7.6$ and stored at $4{ }^{\circ} \mathrm{C}$.

Proteins and their fragments. Fibrinogen was isolated from human blood plasma by a $\mathrm{Na}_{2} \mathrm{SO}_{4}$ salting-out method as previously described [33]. The content of protein that was able to form a clot under the action of thrombin was 96-98\%. The homogeneity of fibrinogen chains was characterized by sodium dodecyl sulfate polyacrylamide gel electrophoresis (SDS-PAGE) in the presence of $0.2 \%$ $\beta$-mercaptoethanol.

Fibrin desA and desAB were obtained from fibrinogen using thrombin that cleaved fibrinopeptides $\mathrm{A}$ and $\mathrm{B}$, and the thrombin-like enzyme ancistron that cleaved fibrinopeptides A exceptionally. The produced fibrin was dissolved in $0.125 \%$ acetic acid [34].

D-dimer was obtained from plasmin hydrolysate of polymerized fibrin desAB by ion-exchange chromatography on KM-Sephadex G 50 (SigmaAldrich) [35, 36].

The N-terminal disulfide knots of fibrin (NDSK of fibrin) were obtained as described by Chudnovets et al. [37-39]. 
Proteases. Protease II was obtained from the culture media of Bacillus thuringiensis var. israelensis IMV B-7465. It was saturated from the supernatant received by precipitation with ammonium sulphate and then obtained as previously described [40].

Protease III was obtained from the culture media of Bacillus sp. that was found in periphyton of a dolphin basin in the Black Sea. Samples were provided by the Scientific Research Centre of Military Forces of Ukraine "State Oceanarium" (Odesa, Ukraine). Bacillus sp. was cultivated for $24 \mathrm{~h}$ in Erlenmeyer flasks during constant agitation $(250 \mathrm{rpm})$ at $28{ }^{\circ} \mathrm{C}$ in culture liquid containing $\mathrm{KH}_{2} \mathrm{PO}_{4}-1.6 \mathrm{mg} / \mathrm{ml}$; $\mathrm{MgSO}_{4} \cdot 7 \mathrm{H}_{2} \mathrm{O}-0.75 \mathrm{mg} / \mathrm{ml}$; $\mathrm{ZnSO}_{4} \cdot 7 \mathrm{H}_{2} \mathrm{O}-0.25 \mathrm{mg} / \mathrm{ml}$; $\left(\mathrm{NH}_{4}\right)_{2} \mathrm{SO}_{4}-0.5 \mathrm{mg} / \mathrm{ml}$; maltose $-1.0 \mathrm{mg} / \mathrm{ml}$; gelatine $-10.0 \mathrm{mg} / \mathrm{ml}$; yeast extract $-0.15 \mathrm{mg} / \mathrm{ml}$; and $\mathrm{pH}-6.5-6.7$ [41]. The fraction of protease was obtained by sedimentation using $90 \%\left(\mathrm{NH}_{4}\right)_{2} \mathrm{SO}_{4}$. The pellet was collected by centrifugation at $5000 \mathrm{~g}$ for $30 \mathrm{~min}$ and was dissolved in $0.01 \mathrm{M}$ Tris- $\mathrm{HCl}$ buffer ( $\mathrm{pH} 7.5)$. The solution was then applied to the column $(2.5 \times 40 \mathrm{~cm})$ with the anion exchanger TSK DEAE 650 (M) (Sigma-Aldrich), with the speed of elution set at $0.85 \mathrm{ml} / \mathrm{min}$.

Methods. ELISA. Antigens solutions $(10 \mu \mathrm{g} / \mathrm{ml})$ were added to the wells of a 96-well plate (Nunc, Roskilde, Denmark). Fibrinogen was in an $0.2 \mathrm{M}$ ammonium-acetate buffer, $\mathrm{pH}$ 8.5. Fibrin was in the same buffer but with $3 \mathrm{M}$ urea added. D-dimer was in bicarbonate buffer, $\mathrm{pH}$ 9.5. Proteins were adsorbed during $16 \mathrm{~h}$ at $4{ }^{\circ} \mathrm{C}$. Then wells were washed using an automatic washing system and poured with a $0.02 \mathrm{M}$ potassium-phosphate buffer that had $0.14 \mathrm{M}$ $\mathrm{NaCl}$ and $0.05 \%$ Tween-20 (TPBS), and then incubated for $3 \mathrm{~min}$ at ambient temperature. After removing the liquid, the solution of primary $\mathrm{mAb}$ to human fibrinogen in TPBS was added to the wells in concentrations ranging from 10 to $0.078 \mu \mathrm{g} /$ $\mathrm{ml}$ and incubated for 1 hour at $37^{\circ} \mathrm{C}$. The wells were washed as described above. Secondary antibody (HRP-conjugated goat anti-mouse antibody (Sigma-Aldrich) was added to the wells at the titer of 1:1000 and incubated for 1 hour at $37^{\circ} \mathrm{C}$. After the washing procedure, the wells were poured with $0.1 \mathrm{ml}$ of $0.05 \mathrm{M}$ potassium-phosphate buffer $\mathrm{pH} 6.0$ that contained 0.03-0.04\% o-phenylenediamine. The reaction was terminated by the addition of $50 \mu \mathrm{l}$ of $2 \mathrm{M} \mathrm{H}_{2} \mathrm{SO}_{4}$. Optical density of the solutions was determined at $492 \mathrm{~nm}$ using the multiplate reader RT 2100C (Rayto, Shenzhen, China).

Production of $m A b .0 .1 \mathrm{mg}$ of antigen mixed 1:1 with complete Freund adjuvant was intraperi- toneally injected into BALB/c mice. Immunization was repeated after 3 weeks using incomplete Freund adjuvant. Presence of specific antibody in the blood serum of immunized mice was determined at 10 days after each successive immunization using ELISA. At 4 weeks after the last injection, before the hybridization the mice were injected with $0.1 \mathrm{mg}$ of antigen in $0.15 \mathrm{M} \mathrm{NaCl}$. Hybridization was performed as previously described [42]. Spleen cells of immunized mice and myeloma cells X63-Ag8.6.5.3 (Flow Laboratories, Sunnyvale, California, United States) were used for the hybridization. It was performed in the presence of 50\% polyethylene glycol, $1450 \mathrm{kDa}$ (Sigma-Aldrich) during 1 min. Cells of the hybridoma were then re-suspended in HAT culture medium (hypoxanthine, aminopterin, thymidine; (Sigma-Aldrich) and 20\% solution of fetal bovine serum Gibco, (Thermo Scientific). Then hybridomas were translocated to a 24-well plate Costar (SigmaAldrich) and cultivated using standard procedure. After 10 days the HAT medium was changed to HT medium (containing hypoxanthine and thymidine) and we performed screening of hybridomas to find the antigen-specific antibody by ELISA. Positive hybridomas were cultivated for multiplication. Antibody was purified from the culture media using affinity chromatography on Fibrinogen-Sepharose or (alternatively) on G-Sepharose (Pharmacia) in $0.01 \mathrm{M}$ potassium-phosphate buffer $\mathrm{pH} 7.2$ with $0.14 \mathrm{M} \mathrm{NaCl}$ and $0.02 \%$ of $\mathrm{NaN}_{3}$ (PBS). Material that bound to G-Sepharose was eluted by $0.1 \mathrm{M}$ glycine$\mathrm{HCl}$ buffer $\mathrm{pH}$ 3.0. Elution from Fibrinogen-Sepharose was performed using $0.2 \mathrm{M}$ glycine- $\mathrm{HCl}$ buffer $\mathrm{pH}$ 2.8. The $\mathrm{pH}$ of the eluted solution of antibody was immediately changed to neutral by adding PBS and concentrating it on the Centrifugal Filter Unit Amicon PM-10 (Merck, Kenilworth, New Jersey, USA).

Study of the isotype of the mAb was performed using ELISA with goat anti-serum to mice immunoglobulin isotypes (Clinical Credential; ICN Immunobiologicals, Lisle, IL, USA).

Determination of dissociation constant $\left(K_{\mathrm{D}}\right)$ of $\mathrm{mAb}$ and fibrin(ogen) was performed using indirect ELISA by the method of Friguet [43] with correction according to Stevens [44].

Antibody biotinylation. For the biotinylation of the $\mathrm{mAb}$ it was dissolved in $0.1 \mathrm{M} \mathrm{NaHCO}_{3}$ buffer pH 9.0 and concentrated on the Centrifugal Filter Unit Amicon PM-10 (Merck) to a final concentration of $1 \mathrm{mg} / \mathrm{ml}$. The N-hydroxysuccinimide derivative of 
biotin (Sigma, USA) was dissolved in dimethyl sulfoxide (DMSO) to the same concentration. Resulting solutions were mixed in a volume:volume ratio of 8:1 (activated biotin vs antibody) and incubated at ambient temperature for $4 \mathrm{~h}$. Then dialysis against PBS in argon atmosphere was performed using the Centrifugal Filter Unit Amicon PM-10 (Merck).

Hydrolysis of fibrinogen. Fibrinogen $(1 \mathrm{mg} / \mathrm{ml})$ was mixed with enzyme $(0.005 \mathrm{mg} / \mathrm{ml})$ in $0.05 \mathrm{M}$ Tris- $\mathrm{HCl}, 0.13 \mathrm{M} \mathrm{NaCl}$ buffer $\mathrm{pH}$ 7.4. The mixture was incubated during $2.5-60 \mathrm{~min}$ at $37{ }^{\circ} \mathrm{C}$. The hydrolysis was terminated by the addition of electrophoresis sample buffer containing 2\% SDS, 5\% glycerine and $2 \% \beta$-mercaptoethanol. Solubilised samples were separated by SDS-PAGE.

$S D S-P A G E$. The molecular weights and purity of proteins were determined by SDS-PAGE using $10 \%$ or $12 \%$ gels accordingly to Laemli [45]. Hydrolysis of fibrinogen and fibrin by proteases was also analyzed by SDS-PAGE under reducing conditions.

Western Blotting was performed by a previously described technique [46]. The separated proteins after SDS-PAGE were transferred to a nitrocellulose membrane in order to specify the bands by immunoprobing. The membrane was blocked with $5 \%$ milk in PBS for one hour, incubated with a mouse mAb for another hour and then developed with a secondary HRP-conjugated goat anti-mouse antibody. The bands were visualized using $0.001 \mathrm{M}$ 4-chloro1-naphtol solution in $0.5 \mathrm{M}$ Tris- $\mathrm{HCl}, \mathrm{pH} 7.5$ and $0.03 \% \mathrm{H}_{2} \mathrm{O}_{2}$.

MALDI-TOF (matrix-assisted laser desorption ionization time-of-flight) mass spectrometry analysis of purified fibrinogenase was performed using a Voyager-DE (Applied Biosystems, Foster City, California, USA). H+-matrix ionization of polypeptides under sinapic acid (Sigma-Aldrich) was used. Results were analyzed by Data Explorer 4.0.0.0 (Applied Biosystems) [47].

To work out the mass of amino acid sequence we used Peptide Mass Calculator (Peptide Protein Research Ltd., Hampshire, UK). It handles n-terminal modifications, oxidized cysteines and phosphorylated amino acids.

Cleavage of chromogenic substrates was studied in microtiter plates by mixing $0.05 \mathrm{M}$ Tris$\mathrm{HCl}$ buffer $\mathrm{pH} 7.4$ containing $0.13 \mathrm{M} \mathrm{NaCl}$ with chromogenic substrates in the concentration range from 25 to $160 \mu \mathrm{M}$, and protease III $(0.005 \mathrm{mg} / \mathrm{ml})$, at $25{ }^{\circ} \mathrm{C}$. Amidase activity of protease III was con- tinuously monitored at $405 \mathrm{~nm}$. The amount of hydrolyzed substrate was calculated using a molar extinction coefficient of $10.500 \mathrm{M}^{-1} \times \mathrm{cm}^{-1}$ for free pNA on reader Multiskan EX (Thermo Scientific) [48].

Sandwich ELISA. Catch-antibody was immobilized on a 96-well plate MaxiSorp (Nunc) in $0.11 \mathrm{ml}$ of PBS $(0.01 \mathrm{mg} / \mathrm{ml})$ and incubated for 18 hours at $4{ }^{\circ} \mathrm{C}$. Then the wells were washed using an automatic washing system, poured with the same volume of TPBS and incubated for 30 minutes at ambient temperature. TPBS was removed from the wells that were then poured with the solutions of antigens in serial dilutions starting from the concentration of $0.01 \mathrm{mg} / \mathrm{ml}$. Plates were incubated for 1 hour at $37^{\circ} \mathrm{C}$. After washing, the wells were poured with $0.1 \mathrm{ml}$ of biotinylated tag-antibody $(1 \mu \mathrm{g} / \mathrm{ml})$ and incubated for 1 hour at $37^{\circ} \mathrm{C}$. Plates were washed as described above and secondary antibody (polymeric HRP-conjugated goat anti-mouse antibody, Sigma) was added to the wells at the titer of 1:6000 and incubated for 1 hour at $37^{\circ} \mathrm{C}$. After the washing procedure, wells were poured with $0.1 \mathrm{ml}$ of $0.05 \mathrm{M}$ potassium-phosphate buffer $\mathrm{pH} 6.0$ that contained $0.03 \%$ of $0.04 \%$ o-phenylenediamine. The reaction was terminated by the addition of $0.05 \mathrm{ml}$ of $2 \mathrm{M}$ $\mathrm{H}_{2} \mathrm{SO}_{4}$. Optical density of the solutions was determined at $492 \mathrm{~nm}$ using the multiplate reader RT 2100C (Rayto, China).

Statistical analysis. Statistical analysis of the data was performed by Student's $t$-test. Statistical calculations were made using MS Excel software (Microsoft Corporation, Redmond, WA, USA). The experimental data were processed with the variation statistics method using OriginPro 8 software (OriginLab, Northampton, MA, USA).

\section{Results and Discussion}

Producing the $m A b$ against the $\alpha C$-region of human fibrinogen. To produce the $\mathrm{mAb}$ against the $\alpha \mathrm{C}$-region of the fibrin(ogen) molecule by the method of hybridoma technology, we used the mixture of isolated chains of fibrinogen for immunization. As a result, hybridoma 1-5A was obtained. It was able to produce antibody towards fibrinogen and fibrin that was purified using Fibrinogen-Sepharose.

Specificity of the mAb was determined by indirect ELISA using the following antigens: fibrinogen, fibrin desAB, D-dimer and NDSK (Fig. 1). It was shown that $\mathrm{mAb} 1-5 \mathrm{~A}$ selectively bound fibrinogen and fibrin desAB but did not interact with $\mathrm{D}$-dimer or NDSK fragments. D-dimer and the NDSK frag- 
ments together comprise almost the entire core of the molecule. Thus, we assumed that the epitope of the newly obtained antibody 1-5A was located in the $\alpha \mathrm{C}$-regions.

Goat anti-serum produced to immunoglobulin isotypes of mice allowed us to determine that $\mathrm{mAb}$ 1-5A belonged to the IgG1 family of immunoglobulins. Antibodies of this isotype are effectively bound to G-Sepharose which can be advantageous for the scaling of their preparation. Direct ELISA by the methods of Friguet [43] and Stevens [44] allowed us to determine the dissociation constant $\left(K_{\mathrm{d}}\right)$ of $\mathrm{mAb}$ $1-5 \mathrm{~A}$ in the reaction with fibrinogen (Fig. 2). It was shown that fibrinogen at the concentration of $2.8 \mu \mathrm{g} /$ $\mathrm{ml}$ decreased by two times the binding of mAb 1-5A adsorbed in the well of the 96-well plate. The calculated $K_{\mathrm{d}}$ was $3.41 \times 10^{-9} \mathrm{M}$ and indicated the high affinity of $\mathrm{mAb} 1-5 \mathrm{~A}$ to fibrinogen.

Localization of the epitope of $m A$ A I-5A. For the preliminary localization of the epitope in the fibrinogen molecule we identified the polypeptide chain that interacted with $\mathrm{mAb} 1-5 \mathrm{~A}$ in the fibrinogen molecule. For this aim, we performed SDSPAGE of fibrinogen under reducing conditions $(0.2 \%$ of $\beta$-mercaptoethanol) in which three chains of fibrinogen moved in the gel separately. mAb 1-5A was used for the detection of the protein in Western blotting. Thus, we showed that the target of $\mathrm{mAb}$ $1-5 \mathrm{~A}$ was specifically the $\mathrm{A} \alpha$-chain of the fibrinogen molecule (Fig. 3).

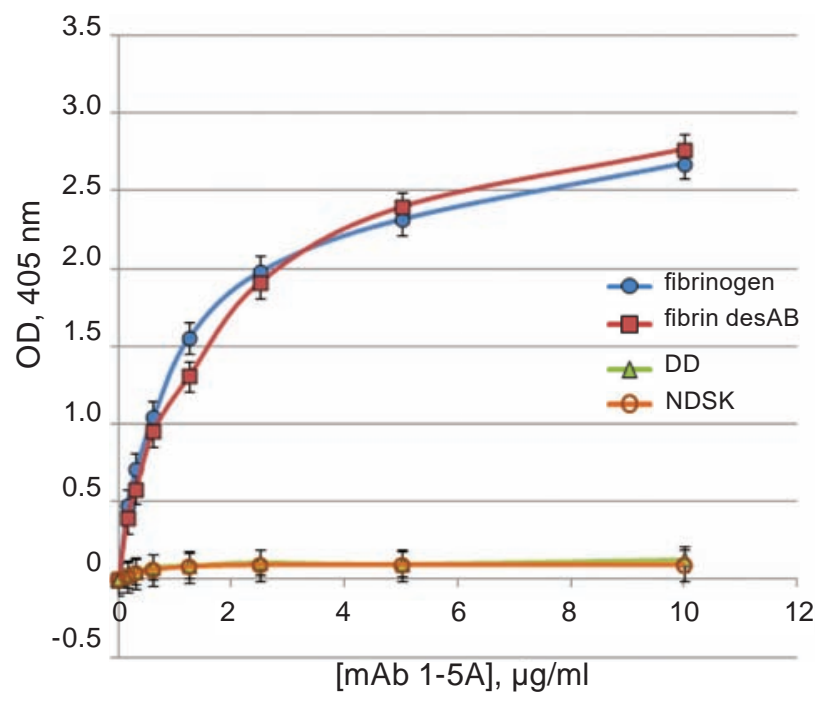

Fig. 1. Binding of monoclonal antibody (mAb) 1-5A to immobilized fibrinogen, fibrin desAB, D-dimer (DD) and N-terminal disulfide knot (NDSK) fragment of fibrin in ELISA

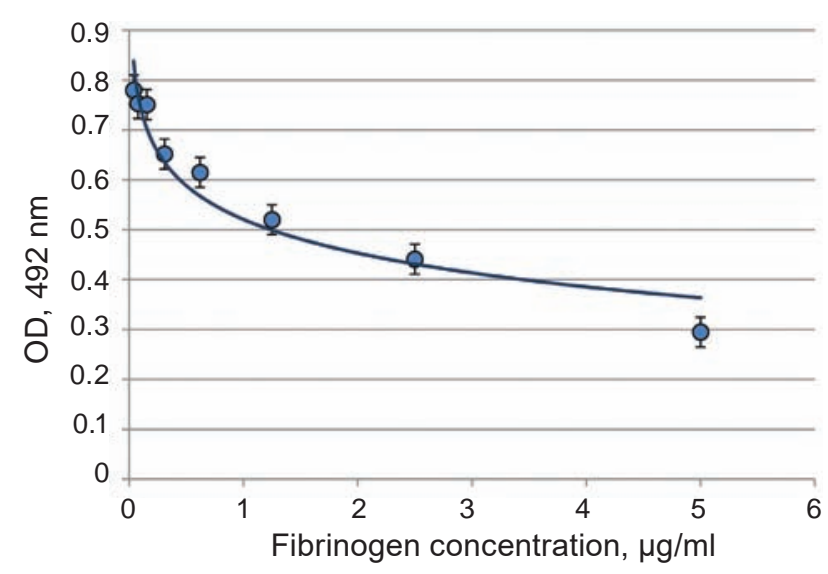

Fig. 2. Concurrent analysis of monoclonal antibody (mAb) 1-5A binding to adsorbed fibrinogen. OD optical density

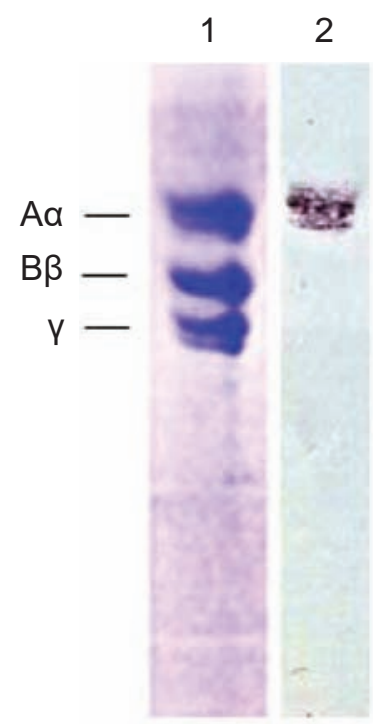

Fig. 3. (1) SDS-PAGE of fibrinogen in the presence of $0.2 \%$ of $\beta$-mercaptoethanol. (2) In 10\% PAGE and corresponding Western blot using monoclonal antibody (mAb) 1-5A for the detection. PAGE - polyacrylamide gel electrophoresis, SDS-sodium dodecyl sulfate

For further localization of the epitope we used two proteases with different specificities, that possessed fibrinogenase activity and cleaved the fibrinogen $A \alpha$-chain. Both enzymes called protease II and protease III were purified from the different Bacillus strains. We studied their action on fibrinogen using Western blotting (Fig. 4).

Previously it was reported that protease II cleaved the peptide bond A $\alpha 504-505$ [49]. The resulting fragment A $\alpha 505-610$ was clearly detected using mAb 1-5A (Fig. 4, A). However no hydrolytic 


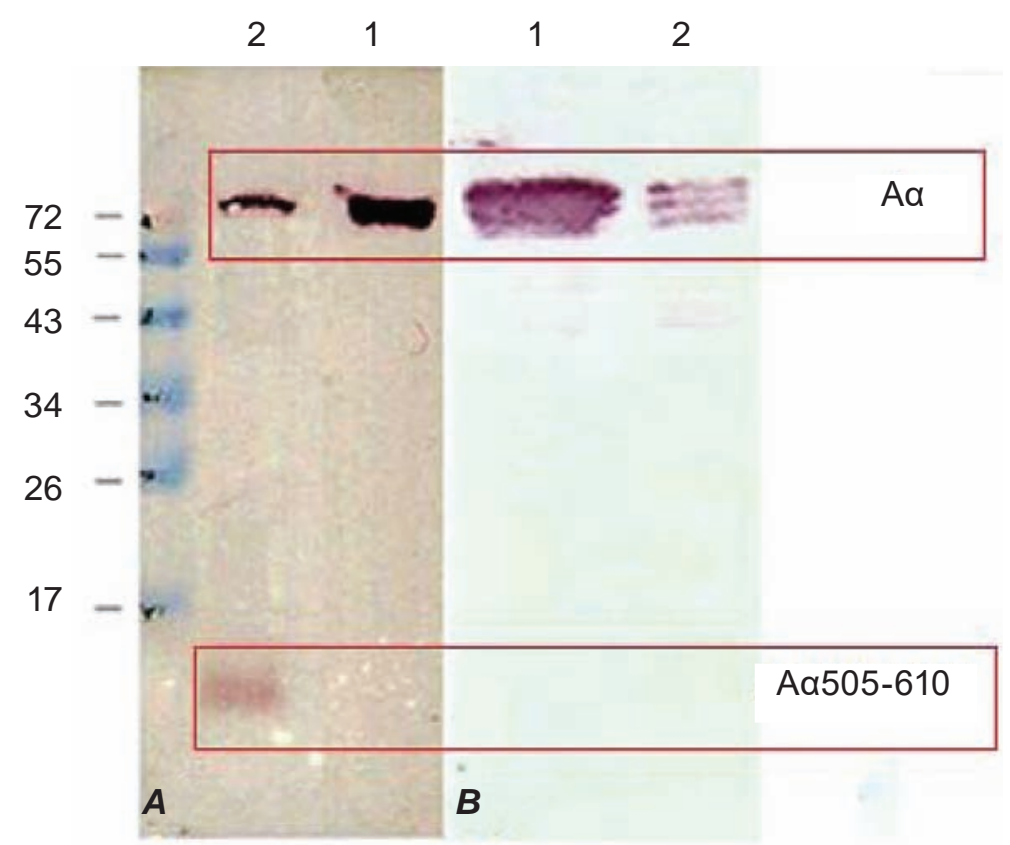

Fig. 4. Western blots of fibrinogen hydrolytic products obtained from the action of (A) protease II and (B) protease III. Time of hydrolysis - $45 \mathrm{~min}$. Monoclonal antibody (mAb) 1-5A was used for the band detection. Lanes $\mathbf{1}$ - sample of fibrinogen before hydrolysis. Lanes $\mathbf{2}$ - sample of fibrinogen after hydrolysis. Upper out-


No fragments were detected in the case of proteolysis by protease III

products of protease III were observed in the same Western blot which may indicate that the epitope of $\mathrm{mAb} 1-5 \mathrm{~A}$ is was destroyed by proteolysis, therefore it overlapped the residues cleaved by protease III. To prove this concept we compared the hydrolysis of fibrinogen by the studied proteases in Western blots using $\mathrm{mAb} 1-5 \mathrm{~A}$ and previously described antibody II-5C with the epitope located in the A $\alpha 20-78$ fragment of fibrinogen [50] (Fig. 5).

Western blotting using mAb II-5C demonstrated that protease III cleaved off the C-terminal portion of the A $\alpha$-chain of fibrinogen with an apparent molecular weight of $6 \mathrm{kDa}$ (Fig. 5, central panel). Western blotting using the novel mAb 1-5A showed the disappearance of the $A \alpha$-chain of fibrinogen and no accumulation of hydrolytic products that can be detected using this antibody (Fig. 5, bottom panel). Thus we concluded that the epitope of $\mathrm{mAb} 1-5 \mathrm{~A}$ is located in fibrinogen fragment A $\alpha 505-610$ and is destroyed under the action of protease III from Bacillus thuringiensis var. israelensis IMV B-7465. So by determining the site of proteolytic cleavage we can detect the epitope of $\mathrm{mAb} 1-5 \mathrm{~A}$.

For the identification of hydrolytic products of proteinase III we used MALDI-TOF analysis. Sev- eral polypeptides were found among the hydrolytic products and were identified as fragments of $A \alpha-$ chains of fibrinogen using the computer server Peptide Mass Calculator (Fig. 6).

Core products of fibrinogen hydrolysis by protease III were polypeptides with the molecular weights of 3928 Da and 3484 Da (Fig. 6). Using Peptide Mass Calculator we identified them as fragments A $\alpha 550-583$ and 553-583. As shown in Fig. 6, both sites of cleavage of fibrinogen by protease III are located in the hydrophobic clusters: IAEF, YKMA. To prove the conclusion that protease III preferentially cleaves peptide bonds surrounded by hydrophobic amino acids, we used substrate analysis and compared the ability of protease III for cleavage of chromogenic peptide substrates that contained different amino-acid residues in S1 and S2 centers. Chromogenic peptide substrates of elastase, thrombin and plasmin (Suc-Ala-Ala-Ala-pNa, H-D-Phe-Pip-ArgpNa and H-D-Val-Leu-Lys-pNa, respectively) were studied. Protease III effectively cleaved the Suc-AlaAla-Ala-pNa substrate. Thus, it was specific for the peptide bond formed by the $\mathrm{COOH}$-terminal group of alanine in the hydrophobic surrounding.

Taking into account the data on protease III specificity towards A $\alpha 549-550,552-553$ and 583-584 


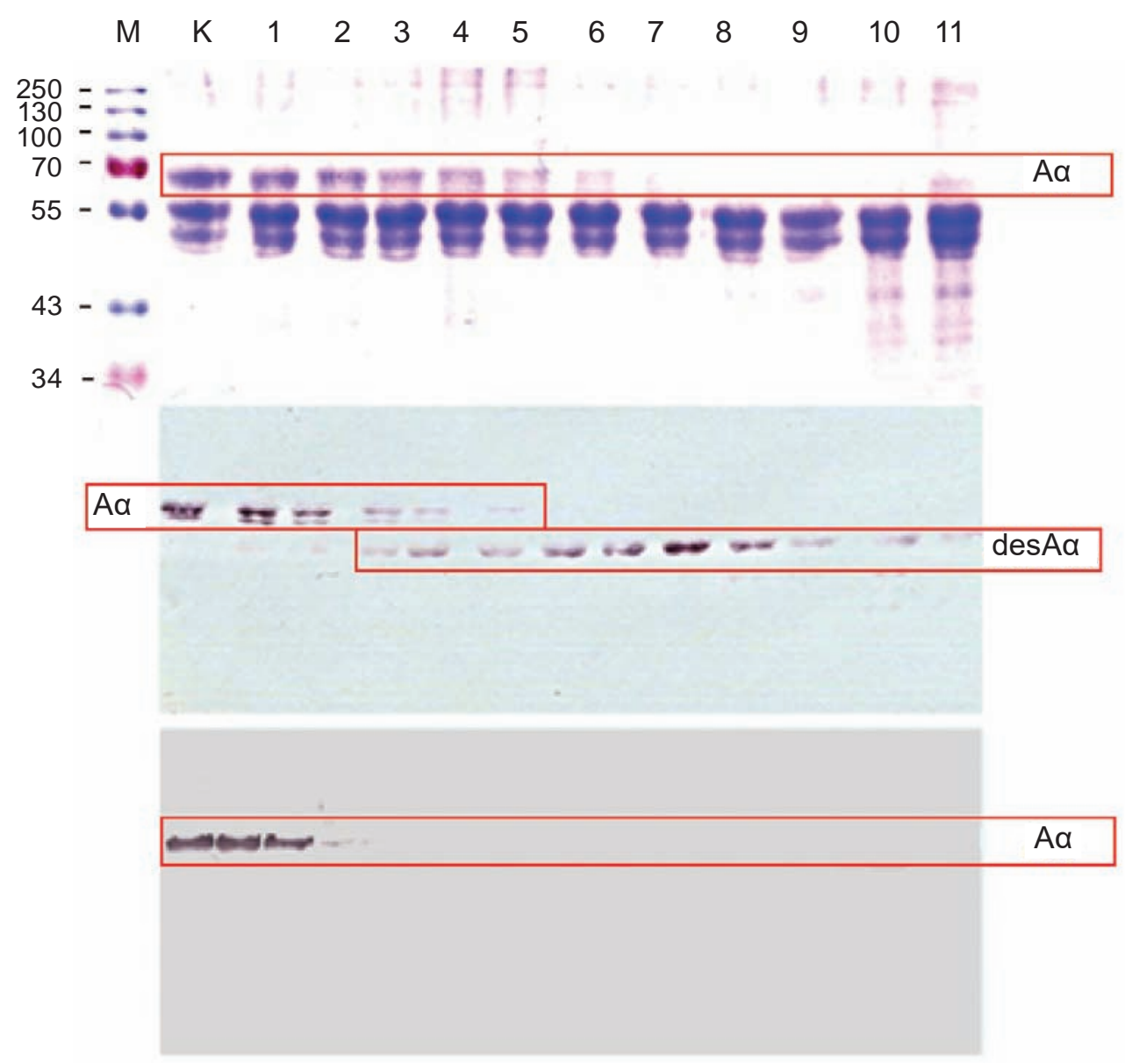

Fig. 5. SDS-PAGE of hydrolytic products of fibrinogen obtained under the action of protease III from the culture media of Bacillus thuringiensis after 2.5-60 min of hydrolysis (top panel, lanes 1-11) and corresponding Western blot (central, bottom panels) using monoclonal antibody (mAb) II-5C and mAb I-5A. Samples were taken after 2.5, 5, 7.5, 10, 15, 20, 25, 30, 40, 50, and 60 min of incubation with protease. Top panel-SDS-

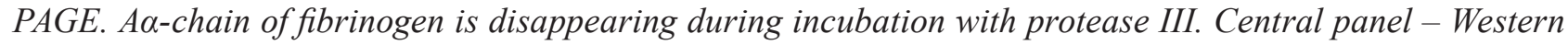
blot using $m A$ A II-5C that interacts with N-terminal portions of the A $\alpha$-chain of fibrinogen. Accumulation of hydrolytic product desA $\alpha$ that contains uncleaved $N$-terminus identified by $m A b$ II-5C indicates that protease

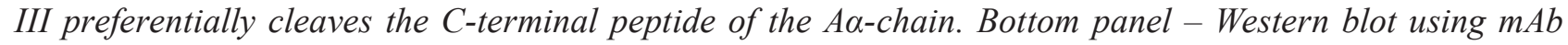

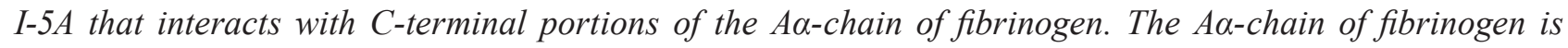
disappearing. No C-terminal peptide containing fragments are found

peptide bonds we can conclude that the epitope of $\mathrm{mAb} 1-5 \mathrm{~A}$ must be destroyed by one of these three cleavage events during the hydrolysis. It is known that epitopes range from 4 to 12 amino acids in size [51]. That is the reason why in determining the epitope of $\mathrm{mAb} 1-5 \mathrm{~A}$ we may count a maximum of 12 amino acid residues to the C-terminal point from the 550th amino acid and a maximum of 12 amino acid residues to the $\mathrm{N}$-terminal point from the 583rd amino acid of the A $\alpha$-chain. Thus, the epitope can be located in the 537-595 fragment of the A $\alpha$-chain.

Approbation of $m A B$ 1-5A as tag-antibody for immunodiagnostics. The high affinity of the created
$\mathrm{mAb} 1-5 \mathrm{~A}$ and its specificity towards the Aa537-595 residue of the $\alpha \mathrm{C}$-region of fibrin(ogen) allowed us to conclude it has potential use in immunodiagnostics.

We previously developed a highly sensitive and effective test-system for the determination of soluble fibrin in human blood plasma [52]. As the catchantibody in this test-system we used fibrin-specific $\mathrm{mAb}$ FnI-3C. As the tag-antibody we used another $\mathrm{mAb}$ (II-4d) that has an epitope in the NH2-terminal fragment of the $\gamma$-chain of the D-region of the fibrin(ogen) molecule [53]. This test-system based on sandwich ELISA allows to perform quantitative determination in human blood plasma of soluble fibrin 


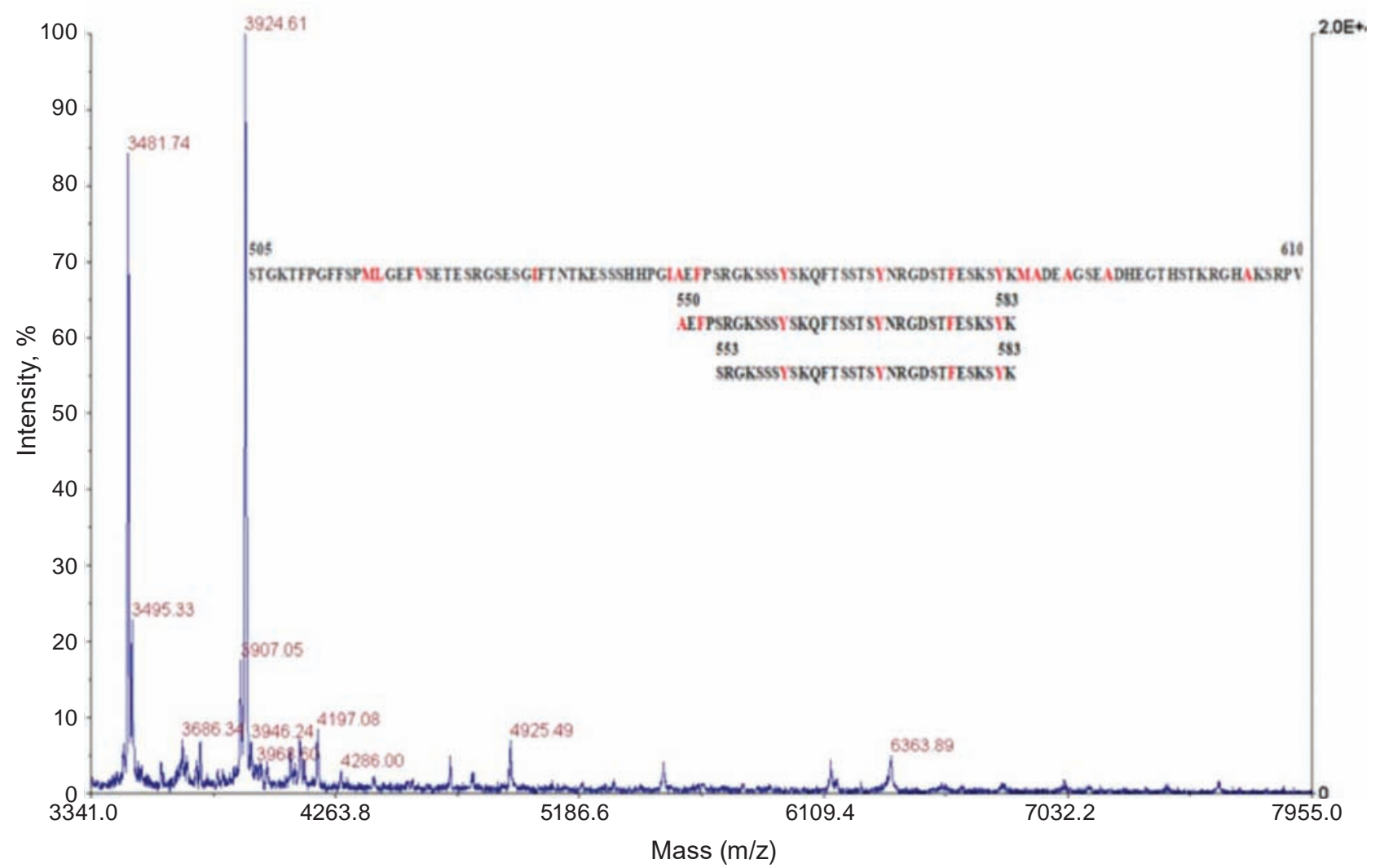

Fig. 6. MALDI-TOF mass spectrometry analysis of polypeptides generated under the action of proteinase III from the culture media of Bacillus thuringiensis on fibrinogen. Central panel-residue of identified polypeptide Aa550-583 and 553-583 that include the epitope of monoclonal antibody (mAb) 1-5A. Hydrophobic amino acids are marked red. MALDI-TOF - matrix-assisted laser desorption ionization time-of-flight

that is composed of monomers, dimers and oligomers of fibrin, possibly with fibrinogen molecules at the sticky ends and also initial products of plasmin hydrolysis of fibrin lacking $\alpha \mathrm{C}$-regions [53].

As far as the epitope of mAb $1-5 \mathrm{~A}$ is located in the Aa537-595 fragment of fibrin(ogen), this antibody can be used as a tag-antibody in sandwich ELISA and exclusively detect the earliest forms of soluble fibrin that were not cleaved by plasmin and preserve $\alpha \mathrm{C}$-regions in their structure. It should be emphasized that these uncleaved forms of soluble fibrin are extremely important as early markers of blood coagulation activation and the danger of thrombus formation [55].

To visualize the possibility of using mAb 1-5A as a detecting tag-antibody in sandwich ELISA for the detection of the earliest forms of soluble fibrin we created a calibration curve with different concentrations of fibrin desAB using the fibrin-specific catch-antibody FnI-3C. We also compared this curve with that obtained using the standard tag-antibody II-4d. Both tag-antibodies were biotinylated (Fig. 7).
The result shown in Fig. 7 confirmed that newly created $\mathrm{mAb} 1-5 \mathrm{~A}$ can be used in sandwich ELISA as a tag-antibody. Being applied in pair with catchantibody FnI-3C it would allow detection of the earliest forms of soluble fibrin. The next task was to prove the possibility of application of this method directly in blood plasma. To achieve this goal we collected samples of blood plasma from patients with stage V chronic kidney disease who were treated by program hemodialysis and determined the earliest forms of soluble fibrin using 1-5A as a tag-antibody. We also determined the total content of soluble fibrin by the same algorithm using II-4d as a tag-antibody (Fig. 8).

The group of patients was selected as a heterogeneous population that is known to manifest thrombophilia, however we could expect patients would have low or high risk of intravascular thrombus formation as well as patients with bleeding [54]. Selection of these patients allowed us to not only test the newly obtained mAb in ELISA, but to also try it with blood plasma samples that have a potentially 


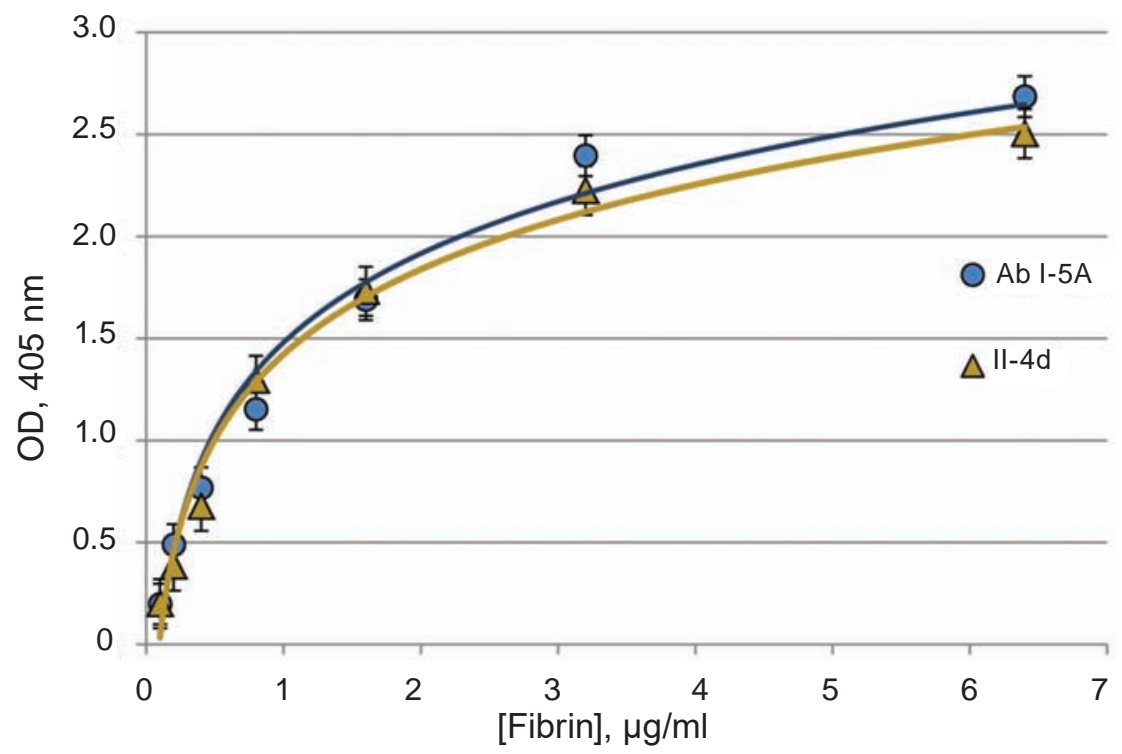

Fig. 7. Calibration curve for the determination of soluble fibrin by sandwich ELISA using fibrin-specific monoclonal catch-antibody FnI-3C and tag-antibodies II-4d (yellow curve) and 1-5A (blue curve) that have epitopes in fragments $\gamma 84-240$ and Aa537-595, respectively. ELISA - enzyme-linked immunosorbent assay, $O D$ - optical density

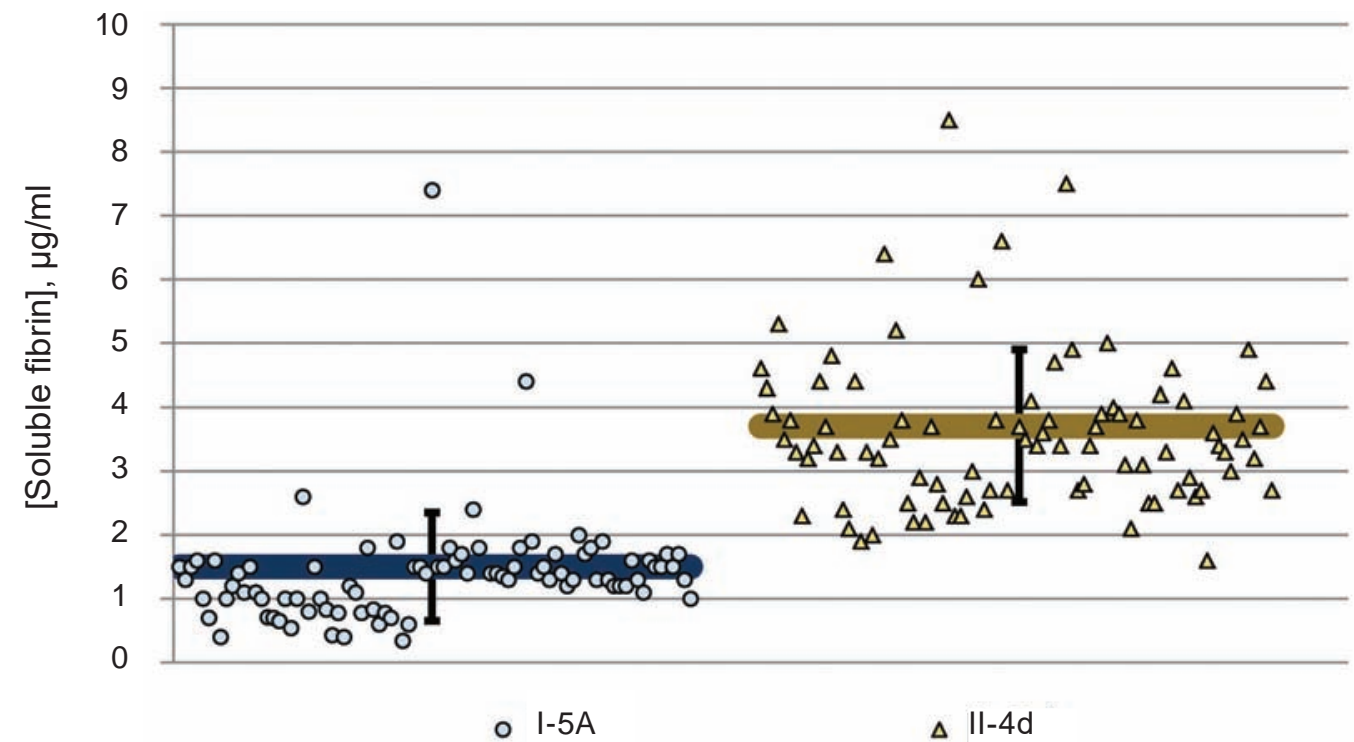

Fig. 8. Quantitative determination of soluble fibrin in blood plasma of patients with stage V chronic kidney disease who were treated by using program hemodialysis. Monoclonal antibodies (mAbs) II-4d (yellow) and I-5A (blue) were used as tags. Fibrin-specific mAb FnI-3C was used as the catch-antibody in both tests. Results are significant for $P \leq 0.05$

wide range of soluble fibrin concentrations - from normal to increased concentrations.

Preliminary analysis allowed us to conclude that the earliest forms of soluble fibrin constitute a small part of total soluble fibrin content. Using II-4d as the tag-antibody allowed us to determine an elevated content of soluble fibrin in blood plasma from
$50 \%$ of the patients. Only several patients also had the earliest forms of soluble fibrin at a concentration of more than $3 \mu \mathrm{g} / \mathrm{ml}$ according to the results of the test performed using 1-5A as the tag-antibody.

We obtained novel mAb 1-5A that had high affinity towards fibrinogen and fibrin but did not react with D-dimer or the NDSK fragment of fibrin. Being 
specific to the fragment 537-595 of the $A \alpha$-chain of the fibrin(ogen) molecule this $\mathrm{mAb}$ can be used both for laboratory diagnostics as well as for probing the fibrinogen molecule structure and functions.

1-5A can be used as a tag-antibody in sandwich ELISA together with the fibrin-specific FnI-3C catch-antibody and allow the determination of the earliest forms of soluble fibrin that are direct evidence of pathological thrombin generation and the danger of intravascular thrombus formation. Being the direct evidence of activation of blood coagulation and generation of thrombin, the concentration of the earliest forms of soluble fibrin can provide additional information of the state of the blood coagulation system in patients and indicate the activation of blood coagulation that is occurring. An additional diagnostic approach developed on the basis of the newly obtained antibody can be applied simultaneously with the existing method of determination of the total content of soluble fibrin indicating the danger of intravascular thrombus formation, allowing estimation of the efficiency of antithrombotic therapy or predicting disease progression. Selection of the conditions for using the newly obtained $\mathrm{mAb}$ for application in the sandwich ELISA technique will allow us to approbate the proposed method and to prove its diagnostic ability in different pathologies connected with the risk of intravascular thrombus formation.

Having a unique specificity towards the structurally labile and functionally active part of the fibrinogen molecule, mAb 1-5A can also be used for studies of the protein-protein and protein-cell interactions of the $\alpha \mathrm{C}$-regions of the fibrin(ogen) molecule. In particular, residue 537-595 of the $\mathrm{A} \alpha-$ chain of the molecule of fibrin(ogen) that was determined to be an epitope of mAb 1-5A can play important roles in platelet receptor recognition, polymerization of fibrin and interactions of endothelial cells during wound healing. Further studies with the use of $\mathrm{mAb} 1-5 \mathrm{~A}$ as the specific inhibitor will allow us to evaluate these roles more precisely.

\section{Conclusion}

An anti-Aa537-595 mAb was obtained and characterized. Its application will contribute to the study of structure and functions of fibrinogen $\alpha \mathrm{C}$ regions and can also be useful for the detection of the earliest forms of soluble fibrin which can be evidence of the risk of intravascular thrombus formation.
This study was funded in the frame of the Ukrainian Government order scientific program according to Agreement № DZ/59-2018 "Development of test-system for simultaneous determination of three molecular markers of intravascular blood coagulation”.

Conflict of interest. Authors have completed the Unified Conflicts of Interest form at http://ukrbiochemjournal.org/wp-content/uploads/2018/12/ coi_disclosure.pdf and declare no conflict of interest.

Acknowledgements. We thank Cedars-Sinai Medical Center's International Research and Innovation in Medicine Program and the Association for Regional Cooperation in the Fields of Health, Science and Technology (RECOOP HST Association) for their support of our organization as a participating Cedars-Sinai Medical Center - RECOOP Research Center (CRRC).

\section{НОВЕ МОНОКЛОНАЛЬНЕ АНТИТІЛО ДО $\alpha$ С-РЕГІОНА ФІБРИН(ОГЕН)У ДЛЯ ВИЗНАЧЕННЯ РАННІХ ФОРМ РОЗЧИННОГО ФІБРИНУ}
Н. Е. Луговська ${ }^{1}$, I. М. Колеснікова ${ }^{1}$, С. М. Стогній А. В. Ребрієв ${ }^{1}$ О. П. Костюченко, Г. К. Гоголінська ${ }^{1}$ Н. А. Дзюблюк ${ }^{2}$ Л. Д. Варбанецьвㄹ, Т. М. Платонова ${ }^{1}$, С. В. Комісаренко

$$
\begin{gathered}
{ }^{1} \text { Інститут біохімії ім. О. В. Палладіна } \\
\text { НАН України, Київ; } \\
{ }^{2} \text { Інститут мікробіології і вірусології } \\
\text { iм. Д.К. Заболотного НАН України, Київ. } \\
\text { घ-mail: bio.cherv@gmail.com }
\end{gathered}
$$

Одержання нових моноклональних антитіл (mAbs) до фібрин(оген)у та його фрагментів $є$ важливим для вивчення механізмів утворення тромбу, пошуку нових антитромботичних агентів та створення імунодіагностикумів. Метою даної роботи було одержати та охарактеризувати нове $\mathrm{mAb}$ до $\alpha \mathrm{C}$-регіона молекули фібрин(оген) у людини. Наявність $\mathrm{mAb}$ до цієї гнучкої частини молекули фібрин(оген)у дозволить вивчити роль їі $\alpha \mathrm{C}$-регіона в процесі полімеризації фібрину, а також розробити імунодіагностичний підхід для виявлення найбільш ранніх форм розчинного фібрину за допомогою бісайтового 
імуноензимного аналізу. Використовуючи гібридомну технологію, ми одержали $\mathrm{mAb}$ $1-5 \mathrm{~A}$ до $\alpha \mathrm{C}$-регіону молекули фібрин(оген)у. Його було охарактеризовано із використанням декількох варіантів імуноензимного аналізу та вестернблот-аналізу. Застосування специфічних протеїназ разом із MALDI-TOF аналізом дозволило нам локалізувати його епітоп у фрагменті 537-595 А $\alpha$-ланцюга молекули фібрин(оген)у. MAb 1-5А може бути використано як детектуюче tag-антитіло в бісайтовому імуноензимному аналізі для кількісного визначення ранніх форм розчинного фібрину, які ще не піддалися розщепленню плазміном i зберігають С-кінцеві ділянки своїх $\alpha \mathrm{C}$-регіонів. Наявність таких ранніх форм розчинного фібрину в кровотоці $\epsilon$ прямим свідченням активації системи зсідання крові, генерування тромбіну та небезпеки утворення внутрішньосудинних тромбів. Їх визначення дасть додаткову більш точну інформацію про стан системи зсідання крові та ризик тромбоутворення, що дуже важливо для своєчасного та правильного підбору адекватної антитромботичної терапії. МАb 1-5A ефективно зв'язує $\alpha \mathrm{C}$-вмісні молекули фібриногену й фібрину в плазмі крові та може бути використане для вивчення протеїно-протеїнових та протеїноклітинних взаємодій $\alpha \mathrm{C}$-регіонів фібрин(оген)у.

К л ю ч о в і с л о в а: моноклональне антитіло, фібриноген, фібрин, $\alpha \mathrm{C}$-регіони молекули фібрин(оген)у, гемостаз, імунодіагностика.

\section{References}

1. Gao Y, Huang X, Zhu Y, Lv Z. A brief review of monoclonal antibody technology and its representative applications in immunoassays. $J$ Immunoassay Immunochem. 2018; 39(4): 351364.

2. Okda F, Lawson S, Liu X, Singrey A, Clement T, Hain K, Nelson J, Christopher-Hennings J, Nelson EA. Development of monoclonal antibodies and serological assays including indirect ELISA and fluorescent microsphere immunoassays for diagnosis of porcine deltacoronavirus. BMC Vet Res. 2016; 12: 95.

3. Ansar W, Ghosh S. Monoclonal antibodies: A tool in clinical research. Indian J Clin Med. 2013; 4: 9-21.

4. Temrikar ZH, Suryawanshi S, Meibohm B. Pharmacokinetics and clinical pharmacology of monoclonal antibodies in pediatric patients. Paediatr Drugs. 2020; 22(2): 199-216.

5. Lu RM, Hwang YC, Liu IJ, Lee CC, Tsai HZ, Li HJ, Wu HC. Development of therapeutic antibodies for the treatment of diseases. $J$ Biomed Sci. 2020; 27(1): 1.

6. Siddiqui MZ. Monoclonal antibodies as diagnostics; an appraisal. Indian J Pharm Sci. 2010; 72(1): 12-17.

7. Lugovskoy EV, Makogonenko EM, Komisarenko SV. Molecular mechanisms of formation and destruction of fibrin. K.: Nauk. Dumka, 2013. 230 p. (In Russian).

8. Lugovskoy EV, Komisarenko SV. Monoclonal antibodies as an instrument to study fibrin polymerization. Bioorg Khim. 2000; 26(12): 883-891. (In Russian).

9. Wolberg AS, Campbell RA. Thrombin generation, fibrin clot formation and hemostasis. Transfus Apher Sci. 2008; 38(1): 15-23.

10. Lugovskoy EV, Gritsenko PG, Kolesnikova IN, Zolotarova EN, Chernishov VI, Nieuwenhuizen W, Komisarenko SV. Two monoclonal antibodies to D-dimer-specific inhibitors of fibrin polymerization. Thromb Res. 2004; 113(3-4): 251-259.

11. Lugovskoi EV, Makogonenko EM, Chudnovets VS, Derzskaya SG, Gogolinskaya GK, Kolesnikova IN, Bukhanevich AM, Sitak IN, Lyashko ED, Komissarenko SV. The study of fibrin polymerization with monoclonal antibodies. Biomed Sci. 1991; 2(3): 249-256.

12. Lugovskoy EV, Gritsenko PG, Kapustianenko LG, Kolesnikova IN, Chernishov VI, Komisarenko SV. Functional role of Bbeta-chain $\mathrm{N}$-terminal fragment in the fibrin polymerization process. FEBS J. 2007; 274(17): 4540-4549.

13. Lugovskoy EV, Chudnovets VS, Makogonenko EM, Derzskaia SG, Gogolinskaia GK, Kolesnikova IN, Mikhalovskaia LI, Komisarenko SV. Study of the polymerization of fibrin using monoclonal antibodies 2D-2A and their Fab-fragments. Ukr Biokhim Zhurn. 1995; 67(1): 64-70. (In Russian).

14. Lugovskoy EV, Gritsenko PG, Kolesnikova IN, Lugovskaya NE, Komisarenko SV. A neoantigenic determinant in coiled coil region of human fibrin beta-chain. Thromb Res. 2009; 123(5): 765-770.

15. Gaffney PJ, Edgell TA, Walker JM. Fibrin polymerisation. Evidence for a secondary 
polymerisation site on the carboxy terminal end of the AA chain using a human fibrin specific murine monoclonal antibody. Ukr Biokhim Zhurn. 1996; 68(4): 43-44.

16. Soe G, Kohno I, Inuzuka K, Itoh Y, Matsuda M. A monoclonal antibody that recognizes a neoantigen exposed in the $\mathrm{E}$ domain of fibrin monomer complexed with fibrinogen or its derivatives: its application to the measurement of soluble fibrin in plasma. Blood. 1996; 88(6): 2109-2117.

17. Török-Nagy B, Antal J, Dénes B. Generation and characterization of $\mathrm{D}$-dimer specific monoclonal antibodies for use in latex agglutination test. PLoS One. 20194; 14(2): e0212104.

18. Koga S. A novel molecular marker for thrombus formation and life prognosis--clinical usefulness of measurement of soluble fibrin monomerfibrinogen complex (SF). Rinsho Byori. 2004; 52(4): 355-361. (In Japanese).

19. Hamano A, Tanaka S, Takeda Y, Umeda M, Sakata Y. A novel monoclonal antibody to fibrin monomer and soluble fibrin for the detection of soluble fibrin in plasma. Clin Chim Acta. 2002; 318(1-2): 25-32.

20. Lugovskoy EV, Kolesnikova IN, Lugovskaia NE, Litvinova LM, Gritsenko PG, Gogolinskaia GK, Liashko ED, Kostiuchenko EP, Remizovskiy GA, Pedchenko VN. Komisarenko SV. Quantification of D-dimer and soluble fibrin in blood plasma of people with ischemic heart disease and hypertension. Ukr Biokhim Zhurn. 2004; 76(6): 136-141. (In Russian).

21. Lugovskoy EV, Kolesnikova IN, Lugovskaya NE, Gritsenko PG, Litvinova LM, Gogolinskaia GK, Liashko ED, Kostiuchenko EP, Golota VIa, Kurochka VV, Komisarenko SV. Soluble fibrin and D-dimer at normal pregnancy and pregnancy with risk of miscarriage. Ukr Biokhim Zhurn. 2006;78(4):120-129. (In Russian).

22. Lugovskoy EV, Efimov DA, Gritsenko PG, Kolesnikova IN, Lugovskaya NE, Litvinova LM, Kostyuchenko EP, Efimov AS, Komisarenko SV. Soluble fibrin and D-dimer as molecular markers of blood vessels complications at diabetes mellitus. Rep Nat Acad Sci Ukraine. 2009; (12): 190-193. (In Russian).

23. Kramareva VN, Gritsenko PG, Kolesnikova IN, Lugovskaya NE, Litvinova AL, Kostyuchenko EP, Lugovskoi EV. Levels of thrombinemia and thrombosis markers in patients with essential hypertension and cardiovascular risk. Nauk Visnyk Med Univ Bogomolets. 2009; (4): 177-181.

24. Lugovska NE. Inventive activity of the Departments of Protein Structure and Function, and Molecular Immunology of the Palladin Institute of Biochemistry of NAS of Ukraine. Part II. National breakthrough in the study and diagnostics of human hemostasis system. $U \mathrm{kr}$ Biochem J. 2016; 88(3): 106-118. (In Ukrainian).

25. Elgundi Z, Reslan M, Cruz E, Sifniotis V, Kayser V. The state-of-play and future of antibody therapeutics. Adv Drug Deliv Rev. 2017; 122: 2-19.

26. Mosesson MW. Fibrinogen and fibrin structure and functions. J Thromb Haemost. 2005; 3(8): 1894-904.

27. Tsurupa G, Mahid A, Veklich Y, Weisel JW, Medved L. Structure, stability, and interaction of fibrin $\alpha \mathrm{C}$-domain polymers. Biochemistry. 2011; 50(37): 8028-8037.

28. Weisel JW, Litvinov RI. Mechanisms of fibrin polymerization and clinical implications. Blood. 2013; 121(10): 1712-1719.

29. Dempfle CE. The use of soluble fibrin in evaluating the acute and chronic hypercoagulable state. Thromb Haemost. 1999; 82(2): 673-683.

30. Lugovskoi EV, Gritsenko PG, Lugovskaya NE, Kolesnikova IN, Komisarenko SV. Molecular composition of soluble fibrin and fibrin degradation products. Methods of their assay. Hematol Transfusiol. 2006; 51(5): 39-43.

31. Suzuki A, Ebinuma H, Matsuo M, Miyazaki O, Yago $\mathrm{H}$. The monoclonal antibody that recognizes an epitope in the $\mathrm{C}$-terminal region of the fibrinogen $\alpha$-chain reacts with soluble fibrin and fibrin monomer generated by thrombin but not with those formed as plasmin degradation products. Thromb Res. 2007; 121(3): 377-385.

32. Heene DL, Matthias FR. Adsorbtion of fibrinogen derivatives on insolubilized fibrinogen and fibrin monomer. Thromb. Res. 1973; 2(2): 137-154.

33. Varetskaya TV. Microheterogeneity of fibrinogen. Cryofibrinogen. Ukr Biokhim Zhurn. 1960; 32: 13-24.

34. Belitser VA, Varetskaja TV, Malneva GV. Fibrinogen-fibrin interaction. Biochim Biophys Acta. 1968; 154(2): 367-375.

35. Lugovskoy EV, Kolesnikova IN, Grisenko PG, Zolotareva EN, Gaffney P, Nieuwenhuizen W, Komisarenko SV. A neoantigenic determinant 
in the D-dimer fragment of fibrin. Thromb Res. 2002; 107(3-4): 151-156.

36. Platonova TN, Musialkovskaia AA, Tolstykh VM, Belitser VA. Inhibition of fibrin assembly by fragment $\mathrm{D}$ and its dimer derived from fibrinogen and stabilized fibrin. Evidence for the two-step type of inhibition. Biokhimiia. 1980; 45(10): 1780-1787. (In Russian).

37. Chudnovets VS, Lugovskoi EV, Gogolinskaia GK, Derzskaia SG, Nazimov IV, The isolation of the NH2-terminal disulfide nodes of human fibrinogen and fibrin and of their constituent polypeptide chain fragments. Dokl Akad Nauk SSSR. 1991; 317(6): 1496-1499. (In Russian).

38. Gårdlund B, Hessel B, Marguerie G, Murano G, Blombäck B. Primary structure of human fibrinogen. Characterization of disulfidecontaining cyanogen-bromide fragments. Eur J Biochem. 1977; 77(3): 595-610.

39. Blombäck B, Blombäck M, Henschen A, Hessel B, Iwanaga S, Woods KR. N-terminal disulphide knot of human fibrinogen. Nature. 1968; 218: 130-134.

40. Matselyukh OV, Nidialkova NA, Varbanets LD. Purification and physicochemical properties of Bacillus thuringiensis IMB B-7324 peptidase with elastolytic and fibrinolytic activity. Ukr Biokhim Zhurn. 2012; 84(6): 25-36. (In Ukrainian).

41. Koltukova NV, Vaskivniuk VT. Selection of methods for the isolation of the proteolytic complex from Bacillus mesentericus $316 \mathrm{~m}$ at deep cultivation. Microbiol Z. 1980; 42(2): 245248. (In Russian).

42. Köhler G, Milstein C. Continuous cultures of fused cells secreting antibody of predefined specificity. Nature. 1975; 256(5517): 495-497.

43. Friguet B, Chaffotte AF, Djavadi-Ohaniance L, Goldberg ME. Measurements of the true affinity constant in solution of antigen-antibody complexes by enzyme-linked immunosorbent assay. J Immunol Methods. 1985; 77(2): 305-319.

44. Stevens FJ. Modification of an ELISA-based procedure for affinity determination: correction necessary for use with bivalent antibody. $\mathrm{Mol}$ Immunol. 1987; 24(10): 1055-1060.

45. Laemmli UK. Cleavage of structural proteins during the assembly of the head of bacteriophage T4. Nature. 1970; 227(5259): 680-685.
46. Tsang VCW, Peralta JM, Simons AR. Enzymelinked immunoelectrotransfer blot techniques (EITB) for studying the specificities of antigens and antibodies separated by gel electrophoresis. Methods Enzymol. 1983; 92: 377-391.

47. Chapman JR. Mass Spectrometry of Proteins and Peptides. Humana Press, 2000, 538 p.

48. Gershkovich AA, Kibirev VK. Chromogenic and fluorogenic peptide substrates of proteolytic enzymes. Bioorg Khim. 1988; 14(11): 1461-1488. (In Russian).

49. Stohniy EM, Chernyshenko VO, Nidialkova NA, Rebriev AV, Varbanets LD, Hadzhynova VE, Chernyshenko TM, Kolesnikova IM, Lugovskoy EV. Mapping of residues of fibrinogen cleaved by Protease II of Bacillus thuringiensis var. israelensis IMV B-7465. Ukr Biochem J. 2016; 88(Special Issue): 79-86.

50. Urvant LP, Makogonenko EM, Pozniak TA, Pydiura NA, Kolesnikova IN, Tsap PY, Bereznitzkiy GK, Lugovskoy EV, Komisarenko SV. Binding of mAb II-5c to A $\alpha 20-78$ fragment of fibrinogen inhibits aneoantigenic determinant exposure within B $\beta 126-135$ site of a molecule. Dopov Nac Akad Nauk Ukr. 2014;5:149-156. (In Ukrainian).

51. Buus S, Rockberg J, Forsström B, Nilsson P, Uhlen M, Schafer-Nielsen C. High-resolution mapping of linear antibody epitopes using ultrahigh-density peptide microarrays. Mol Cell Proteomics. 2012;11(12):1790-1800.

52. Lugovskoy EV, Kolesnikova IN, Komisarenko SV. Usage of monoclonal antibodies for determination of localization of antigenic determinants and fibrin polymerization sites within fibrinogen and fibrin molecules and their application in test-systems for diagnostics and the threat of thrombus formation. Biotechnologia Acta. 2013; 6(4): 33-42.

53. Lugovskoi EV, Gritsenko PG, Komisarenko SV. Molecular mechanisms of the polymerization of fibrin and the formation of its three-dimensional network. Bioorg Khim. 2009; 35(4): 437-456. (In Russian).

54. Grupp C, Troche-Polzien I, Stock J, Bramlage C, Müller GA, Koziolek M. Thrombophilic risk factors in hemodialysis: Association with early vascular access occlusion and patient survival in long-term follow-up. PLoS One. 2019; 14(9): e0222102. 